JPH: Jurnal Pembaharuan Hukum

Volume 8, Number 3, December 2021

\title{
THE COMPARISON OF LEGAL DAMAGES FOR COPYRIGHT \& BRAND INFRINGEMENT AMONG INDONESIA-CHINA LAWS
}

\author{
Heri Gunawan \\ Universitas Sriwijaya Palembang, South Sumatera, Indonesia \\ herigunanot@gmail.com \\ Joni Emirzon \\ Universitas Sriwijaya Palembang, South Sumatera, Indonesia \\ joniemirzon@yahoo.co.id \\ Muhammad Syaifuddin \\ Universitas Sriwijaya Palembang, South Sumatera, Indonesia \\ muhammad.syaifuddin.2871973@gmail.com
}

\begin{abstract}
Intellectual Property Rights or what is often abbreviated as HAKI is a legal protection given by a certain country to a person or group of individuals who express their ideas in the form of works. This law is a state territory. This means that a work will only be protected by rights in the country where the work originated to obtain IPR. As stated in the Copyright Laws, Intellectual Property Rights are exclusive rights granted by a regulation to a person or group of people for their copyrighted works. This protected work is in the form of intangible objects such as copyrights, patents, and trademarks and tangible objects in the form of information, technology, literature, art, skills, science, and so on. The idea of compensation law for copyright and trademark infringement in Indonesia, of course, can imitate the copyright law and trademark law of the People's Republic of China in regulating more clearly the calculation of the value of losses for copyright and trademark infringement in order to be able to provide legal certainty for the owner / rights holders whose rights have been violated. The research use normative juridical approach. The purpose of writing is to analyze and explain the calculation of compensation by looking at the criteria, evidence, basis, form and formulation of calculating compensation for copyright and trademark infringement. The results of the study stated that the law for compensation that arises as a result of copyright and trademark infringement according to positive law in Indonesia still does not regulate in detail the calculation of the value of the loss of both copyrights and trademarks. Copyright Act No.28 of 2014 and Trademark Act No.20 of 2016 only gives rights to the right owner/right holder to file a claim for compensation, but the law does not regulate how to determine the value of the loss for a copyright infringement as well as brands.
\end{abstract}

Keywords: Comparison; Copyright; Infringement; Trademarks. 


\section{A. INTRODUCTION}

Intellectual property rights (IPR) according to OK. Saidin in his book on the Legal Aspects of Intellectual Property Rights, are material rights, the right to an object that comes from the work of the brain, the result of ratio work, the result of the work of reasoning human ratios, the work is in the form of immaterial objects (intangible object) ${ }^{1}$. Property Rights is the right to enjoy the usefulness of a material freely, and to act freely. ${ }^{2}$ IPR is becoming an increasingly interesting issue to study because of its increasingly decisive role in the acceleration of national development, especially in the era of globalization. In this connection.

In the post-GATT (General Agreement on Tariff and Trade) era of globalization and the era of the WTO (World Trade Organization) there are important issues that are included in the structure of the WTO institution, namely TRIPs (Trade Related Aspects of Intellectual Property Right) which specifically manages matters relating to Intellectual Property Rights. ${ }^{3}$

The importance of protecting intellectual property rights cannot be separated from the long process that has been passed, ${ }^{4}$ there is a guarantee of legal certainty of justice on the work of people who have intellectual property is very important to be protected. Talking about justice, of course, cannot be separated from what is called "Rights", a person's right to demand justice for his creations, namely the right to intellectual products. The view of abuse of rights (eg van recht or abuse de droit) is associated with the idea that existing rights are not only given for individual interests, but must also be aimed at improving the welfare of the community. ${ }^{5}$. Abuse of rights occurs when a person uses his rights in a way that is contrary to the purpose for which the rights were granted. In other words, contrary to the purpose of society ${ }^{6}$. Likewise, the use of rights without an interest can be declared as abuse of rights ${ }^{7}$. This abuse of rights is one of the problems in an effort to protect one's intellectual output.

Intellectual Property Rights development regulations are in line with the attitude of appreciation, respect, and protection that will not only provide a sense of security, but will also create a conducive climate for

1 OK. Saidin, Aspek Hukum Hak Kekayaan Intelektual, Rajawali Pers, Jakarta, 2002, page 9.

2 Anis Mashdurohatun, Lily Mariam Nasution, Copyright Transfer of Inheritance Based on Justice Value, International Journal of Innovation, Creativity and Change, Vol. 12, No. 12, 2020, page.1265-1281

3 Oksidelfa Yanto, Konsep Perlindungan Hak Cipta Dalam Ranah Hukum Hak Kekayaan Intelektual (Studi Kritis Pembajakan Karya Cipta Musik dalam Bentuk VCD dan DVD), Yustisia, Vol. 4 No. 3 September-December 2015, page746-760

4 Ahmad M. Ramli, Rika Ratna Permata etc, Pelindungan Kekayaan Intelektual Dalam Pemanfaatan Teknologi Informasi Di Saat Covid-19, Jurnal Penelitian Hukum De Jure Volume 21 Nomor 1, March 2021, page45-58

5 Rahmi Jened Parinduri Nasution, Interface Hukum Kekayaan Intelektual dan Hukum Persaingan (penyalahgunaan HKI), PT RajaGrafindo Persada, Jakarta, 2013, page 285.

6 Oetarid Sadino, Pengantar IImu Hukum (Terjemahan Ineiding tot de Studie van het Nederlandse Recht karangan L.J. van Apeldoorn), Pradnya Paramita, Jakarta, 1993, page 53.

7 Ibid., page 54. 
increasing enthusiasm to produce bigger, better, and more works. ${ }^{8}$ The philosophy of IPR protection is to encourage the progress and emergence of new ideas and to create a climate conducive to the benefit of spreading these ideas. With this protection, creators and inventors will receive financial rewards, while the public will enjoy and develop the creations obtained from this intellectual thought. So, the concept of IPR protection is not only for the rights of the inventor or creator, but also for the IPR users themselves ${ }^{9}$. Violation of IPR can also be interpreted as a violation on Human Rights, because intellectual property is a basic right inherent in humans by nature which is produced from within a human being through his intellectual abilities.

Compensation as a form retaliation for violation what has been done that has harmed someone, either in the form of material loss as well as immaterial. Copyright and trademark laws have regulated the right to obtain compensation for violations that occur, in Act No. 28 of 2014 concerning Copyright Article 1 number 25 states that what is meant by "compensation is the payment of a sum of money charged to the perpetrators of the violation of the economic rights of the Author, Copyright Holder and/or Related Rights owner based on a court decision in a civil or criminal case that has permanent legal force for the losses suffered by the Author, Copyright Holder and/or Related Rights owner". Constitution the mark does not explicitly state the meaning of the compensation. In civil law, the emergence of a lawsuit basically is from an unlawful act and default. A lawsuit against the law can be requested for compensation materially and immaterially, while a lawsuit against a default is only for compensation materially only ${ }^{10}$.

Dispute resolution in violation what happened to IPR is an important thing for the realization of justice intellectuals in creating their intellectual works. Settlement of disputes through lawsuits going to court is a form of as a way to fulfill a sense of justice for the owner of intellectual property, a lawsuit in the form of a claim for compensation becomes a mandatory thing to be fulfilled, considering that a result of intellectual property is wealth for the owner which of course has economic value. In order for order and peace to be well maintained, the law must be in accordance with the legal ideals of the people of the country ${ }^{11}$. Law enforcement in Indonesia to date continues to experience development, in accordance with very rapid technological developments and developments in society.

The importance of law enforcement that fulfills a sense of justice intellectual property owners really need to follow developments in order to

8 Maria Alfons, Implementasi Hak Kekayaan Intelektual Dalam Perspektif Negara Hukum, Jurnal Legislasi Indonesia, Vol. 14 No. 03 - September 2017, page 357 - 368

9 Fathoni, Paradigma Hukum Berkeadilan Dalam Hak Kekayaan Intelektual Komunal, Jurnal Cita Hukum, Volume II No. 2, 2014, page 293.

10 Chuasanga A., Ong Argo Victoria. (2019). Legal Principles Under Criminal Law in Indonesia and Thailand, Jurnal Daulat Hukum, Vol 2, No 1, 2019

11 I Made Sukadana, Mediasi Peradilan (Mediasi Dalam Sistem Peradilan Perdata Indonesia Dalam Rangka Mewujudkan Proses Peradilan Yang Sederhana, Cepat dan Biaya Ringan), PT. Prestasi Pustaka Publisher, First Printed, Jakarta, page 2. 
provide a sense of justice for intellectual property owners. According to Satjipto Raharjo, law enforcement is essentially the enforcement of ideas or concepts about justice, truth, social benefits and so on.

Based on the above background, the writer can formulate a problem in the form of a) How is the law of restitution loss arising as a result of a violation of copyrights and trademarks according to the rules of positive law in Indonesia and the People's Republic of China. (2) What is the idea of compensation law on violation Copyright and trademarks in Indonesia in terms of legal certainty in the future. Therefore, the author is interested in examining the Comparison of Laws for Compensation for Copyright and Trademark Infringement among Indonesia and the People's Republic of China.

\section{B. RESEARCH METHODS}

The approach method using normative juridical or legal research with a normative doctrinal approach, or normative juridical legal research or normative legal research is basically an activity that will examine internal aspects (to solve problems that exist in) positive law. ${ }^{12}$ On the one hand, the science of law with its original character as a normative science and on the other hand the science of law has empirical aspects. The empirical side is the study of empirical legal science such as sociological jurisprudence, and socio legal jurisprudence. Thus, from this point of view, normative jurisprudence has a unique method of study. Empirical law can be studied through quantitative or qualitative research. ${ }^{13}$

\section{RESULTS AND DISCUSSION}

\section{Compensation for Copyright and Trademark Infringement in In- donesia Law}

a. Copyright Compensation Law

Copyright is an intellectual property in the field of science, art and literature that has a strategic role in supporting the development of the nation and advancing the general welfare as mandated by law. 1945 Constitution of the Republic of Indonesia. Copyright according to Act No. 28 of 2014 concerning Copyright is the exclusive right of the creator that arises automatically based on declarative principles after a work is realized in the form of without reducing restrictions in accordance with the provisions of the legislation. Creation as defined in the Act Copyright is the result of each creator's work in a

12 Kornelius Benuf, Muhamad Azhar, Metodologi Penelitian Hukum sebagai Instrumen Mengurai Permasalahan Hukum Kontemporer, Jurnal Gema Keadilan, Volume 7 Edition I, June 2020, page 20-33

13 Laurensius Arliman S, Peranan Metodologi Penelitian Hukum Di Dalam Perkembangan Ilmu Hukum di Indonesia, Soumatera Law Review, Vol 1, No 1, 2018, page112-132 
distinctive form and shows its authenticity in the fields of science, art and literature ${ }^{14}$.

The increasingly rapid development in the fields of science, technology, art and literature raises the need for increased protection and guarantees of legal certainty for creators, copyright holders, and also related rights owners ${ }^{15}$. In accordance with the purpose of copyright law protection, namely to prevent the occurrence of a legal event that is detrimental to the creator ${ }^{16}$.

Copyright as part of intellectual property rights which is property, especially the law of objects (zakenrecht) which has intellectual property objects, namely intangible objects that are immaterial., then the owner of intellectual property rights in principle can do anything according to his will ${ }^{17}$. As a wealth, of course, it has economic value, so in practice it is not uncommon for copyright to be the object of dispute. The occurrence of a copyright dispute is caused by a violation against copyrights that are carried out by others without the right to use the copyright. Copyright infringement can be defined as the use of a copyrighted work that violates the exclusive rights of the copyright holder, such as the right to produce, reproduce, distribute, and exhibit the work of others without the rights/permission of the rights holder.

Violation is an act that is contrary to the applicable provisions. Copyright law also stipulates that infringement of Copyright can occur if there are parties who commit acts as regulated in Article 112 to Article 118 of the Copyright Law.

Based on Act No. 28 of 2014 concerning Copyright, it can be concluded that the criteria for violation copyright as follows:

1) Carry out commercial use of the work regulated in Article 40 without the permission of the Author, Copyright Holder or Related Rights Owners in the form of piracy, broadcasting, copying, distribution of works. As regulated in Article 9 paragraph (1).

2) Remove, alter or destroy copyright management information and copyright electronic information, as regulated in Article 7.

3) Damaging, destroying, eliminating, or making non-functioning technological control facilities used to protect Works or Related Rights products as well as Copyright safeguards or Related Rights, as regulated in Article 52.

14 Ajib Rosidi, Undang-Undang Hak Cipta Pandangan Awam, (Jakarta: Djambatan, 2002), page 18.

15 Muchtar Anshary Hamid Labetubun, Aspek Hukum Hak Cipta Terhadap Buku Elektronik (E-Book) Sebagai Karya Kekayaan Intelektual, Jurnal SASI, Volume 24, No. 2, 2018, page 147.

16 Kantaadmadja, Mieke Komar dan Ramli, Ahmad M, Perlindungan Atas Hak Kekayaan Intelektual Masa Kini Dan Tantangan Menghadapi Era Globalisasi Abad 21, (Bandung: Alumni, 2007), page 40.

17 Elisabeth Nurhaini Butarbutar, Hukum Harta Kekayaan Menurut Sistematika KUHPerdata dan Perkembangannya, (Medan: Refika Aditama, 2012), page 52. 
4) Providing a trading place that sells or duplicates goods resulting from violations, as regulated in Article 10.

5) Carry out commercially, copying, announcement, distribution, and/or communication of portraits without written permission from the person being photographed or their heirs, as regulated in Article 12.

6) Carry out commercial use of the work in a show without the author's permission, as regulated in Article 23 paragraph (2).

7) Hijacking a Phonogram Producer, as regulated in Article 24 paragraph (2).

8) Hijacking broadcasting institutions, as regulated in Article 25 paragraph (2).

For violations that occur, the copyright law has regulated by giving rights to the Creator, Copyright Holder and Related Rights Holder to file a claim for compensation to the Commercial Court, as regulated in Article 96 paragraph (1) of the Copyright Law. However, although the Copyright Law has provided for the right to file a claim for compensation for a copyright infringement, neither the law nor other implementing regulations have regulated the formulation for calculating the amount of compensation. The existence of a formulation for calculating the amount of compensation as a guide or reference, not only for law enforcers such as judges to determine the amount of compensation that is fair for the parties but will also be helpful for the parties themselves as well as for stakeholders related to calculating the amount of compensation due to violations of copyright.

In practice, when there is a copyright dispute in the Commercial Court, the judge has difficulty determining the amount of compensation in his decision. This is because there are no rules that clearly regulate the formulation of calculating the amount of compensation for copyright infringement. So that the judge in giving his decision is based on the judge's own belief judging from the evidence proven in the trial.

b. Trademark Compensation Law

Under the Act No. 20 of 2016 concerning Brands and Geographical Indications Article 1 point 1, Mark is a sign that can be displayed graphically in the form of images, logos, names, words, letters, numbers, color arrangement, in the form of 2 (two) dimensions and/or 3 (three) dimensions, sound, hologram, or a combination of 2 (two) or more of these elements to distinguish goods and/or services produced by individuals or legal entities in the activities of trading goods and/or services. Article 1 number 2 Trademarks are marks used on goods traded by a person or several persons or legal entities to distinguish them from other similar goods. Article 1 point 3 Service Marks are Marks used for services traded by 
a person or several persons jointly or by a legal entity to distinguish them from other similar services.

In interactions and transactions among producers and consumers, brands play a role in representing producers to present themselves to characterize themselves as products that make it easier for consumers to find goods or services. So that the brand that has been known to consumers has economic value as a guarantee of the quality of the product ${ }^{18}$.

Brand on an item needs to be protected because the mark contains intellectual property rights that can bring economic benefits to the owner of the trademark rights ${ }^{19}$.As a part of intellectual property rights such as copyright, it will also often be the object of dispute because of the economic value it has. The occurrence of disputes over trademark infringement is certainly strongly influenced by the high economic value factor in the brand of goods or services. The higher the economic value of a brand, the more it will become an object that is violated in order to get a big advantage for the violator. Mark infringement occurs as a result of other parties using a mark that has similarities in principle or in its entirety for similar goods and/or services. Mark infringement is the use of a mark by another party that has similarities in principle or in its entirety for similar goods and/or services without the right/permission of the mark owner.

Mark infringement can be interpreted as an act that is contrary to the provisions of the trademark legislation in the form of commercial use of a brand of goods/services without the permission of the registered mark owner. On violation the registered mark owner and/or licensee may file a claim for compensation.

Constitution Number 20 of 2016 concerning Brands and Geographical Indications Article 83 paragraph (1) reads:

"Brand Owner registered and/or Licensee Registered trademarks can file a lawsuit against other parties who unlawfully use a Mark that has similarities in principle or in its entirety for similar goods and/or services in the form of:

1) lawsuit replace and/or

2) termination of all actions related to the use of the Mark the".

Article 83 paragraph (1) clearly states the criteria for violation trademark in the form of "other parties who unlawfully use the Mark"which has similarities in principle or in its entirety for similar goods and/or services". So it can be concluded that an act that

18 Mukti Fajar ND, Yati Nurhayati, dan Ifrani, Itikad Tidak Baik Dalam Pendaftaran Dan Model Penegakkan Hukum Merek di Indonesia, Jurnal Hukum IUS QUIA IUSTUM No. 2, Vol 25, 2018, page 220.

19 Jisia Mamahit, Perlindungan Hukum Atas Merek Dalam Perdagangan Barang Dan Jasa, Jurnal Lex Privatum, Vol 1, No. 3, 2013, page 90. 
violates a mark is the use of a brand of similar goods/services that have similarities in principle or in its entirety without the permission of the brand owner.

The provisions in Article 83 paragraph (1) serve as the basis for compensation on violation registered trademark because it gives rights to the Mark Owner and/or Licensee Brand to file a lawsuit compensation to the Commercial Court. The elements of trademark infringement in Article 83 paragraph (1) include: ${ }^{20}$

1) Illegally using a brand, Shows that the perpetrator is not the owner of the brand who has exclusive rights. Perpetrators use other people's brands without first asking permission.

2) Brand have similarities in principle or in its entirety, that the actor's mark has similarities in that the two marks have similarities to each other and overall are the marks exactly the same as the registered mark belonging to the owner.

3) For similar goods or services.

4) Brand used by the perpetrator for goods or services similar to the goods or services of the registered mark owner.

As regulated in Article 83 paragraph (1) that in the event of a mark infringement, the Registered Mark Owner and/or Registered Mark Licensee may file a claim for compensation to the Commercial Court. However, the current Trademark Law and other implementing regulations have not yet regulated the formulation for calculating the amount of compensation. When the loss suffered because there are other parties whose actions can be classified as violations rights, then the loss caused by the party must be replaced with the aim of restoring the situation as before ${ }^{21}$. This compensation is called compensation $^{22}$. So that in practice it is the same as copyright, in the case of a copyright dispute in the Commercial Court, the judge has difficulty determining the amount of compensation in his decision. This is because there are no rules that clearly regulate the formulation of calculating the amount of compensation for trademark infringement.

\section{Compensation for Copyright and Mark Infringement in the Peo- ple's Republic of China Law}

a. Copyright Compensation Law

In China, copyright law is regulated in the Copyright Act of The People's Republic of China Of 2020, which takes effect on June 1, 2021, is the third amendment to the Copyright Law of the People's Republic of China of 2010 and 2001. This latest amendment

20 Chandra Gita Dewi, Penyelesaian Sengketa Pelanggaran Merek, Deepublish, Yogyakarta, 2019), page 169.

21 Ibid., page 169.

22 Ibid. 
enhances the previous law, one of which is very important is the change in the regulation regarding compensation for copyright infringement.

Article 1 states that the purpose of this law is to protect the copyrights of the creators of literary, artistic and scientific works as well as their rights related to copyright, to encourage the creation and dissemination of works that are beneficial to the development of socialist spiritual civilization and material civilization, and to promote development and development. Socialist culture and scientific endeavor. Prosperity, this law is promulgated in accordance with the Constitution. What is meant by "works" in China's copyright law are intellectual works that are original and can be realized in certain forms in the fields of literature, art, and science, including: (1) written works; (2) oral works; (3) music, drama, folk art, and dance, acrobatic works of art; (4) fine arts, architectural works; (5) photographic works; (6) Audiovisual works; (7) engineering design drawings, product design drawings, maps, schematic diagrams, etc. Graphic works and models; (8) computer software; (9) other intellectual achievements that meet the characteristics of the work.

China as one of the developed countries that is experiencing very rapid development both in terms of development and economy, is even now one of the world's economic powers besides the United States. With the increasingly rapid economic development, of course, economic activities related to intellectual property rights, especially copyrights, will certainly be increasingly important to protect. Rapid economic development will of course always be followed by legal developments that must be able to accommodate. Copyright which consists of works, arts and sciences which are also objects in the economic movement must be protected from various kinds of violations by irresponsible people.

China's copyright law stipulates that every person who infringes on copyright must be held civilly responsible, starting from stopping the infringement, eliminating the impact of the infringement, apologizing to compensating for damages according to the conditions and level of infringement, these violations are:

1) Publish the work without the permission of the copyright owner;

2) Without permission from the creator, publish a work created in collaboration with others as his own creation;

3) Not participating in creation, seeking personal fame and fortune, signing other people's work;

4) Distorting or falsifying the work of others;

5) Plagiarizing the work of others;

6) Without permission from the copyright owner, use the work for exhibition purposes, film audio-visual works, or use the work in adaptation, translation, annotation, etc., unless otherwise provided by law;

7) Use of other people's work without payment; 
8) Without the permission of the copyright owner, performer, or producer of the audio-visual work, computer software, or audiovisual product, rent the originals or copies of their audio-visual works or products, unless otherwise provided by law;

9) Using the layout design of the publisher's books and magazines without the publisher's permission;

10)Without the permission of the performer, broadcast live or transmit his live performance publicly, or record his performance;

11)Other acts of copyright infringement and copyright related rights23.

In addition, China's copyright law also regulates any person who commits the following offences:

a) Copying, distributing, displaying, screening, broadcasting, compiling, or distributing the work to the public through information networks without the permission of the copyright owner, unless otherwise provided by law;

b) Publish books for which others enjoy exclusive publishing rights;

c) Copy and distribute audio and video recordings of their performances, or disseminate their performances to the public through information networks without the permission of the actors, unless otherwise provided by law;

d) Copy, distribute, or disseminate the resulting audio and video products to the public through the information network without the permission of the audio and video producer, unless otherwise provided by law;

e) Broadcast, copy, or disseminate radio and television to the public through information networks without permission, unless otherwise provided for in the law;

f) Those who knowingly circumvent or destroy technological acts without the permission of the copyright owner or relevant rights holders, knowingly manufacture, import, or otherwise provide to others devices or components primarily used to avoid or destroy technological acts, or intentionally Provide technical services to others to avoid or destroy technical actions, unless otherwise provided by laws and administrative regulations;

g) Any person who knowingly deletes or changes the rights management information for a work, layout design, performance, audio or video recording, or radio or television without the permission of the copyright holder or copyright related rights holder, knows or should know the work, design layouts, performances, audio and video recordings, or rights management information on radio and television removed or changed without permission and are still made available to the public, unless 
otherwise provided by administrative laws and regulations;

h) Create and sell works that forge other people's signatures ${ }^{24}$.

China's copyright law has regulated the law of compensation in the event of copyright infringement above, as follows:

1) In case of violation of copyright or copyright related rights, the infringer must pay compensation based on the actual loss suffered by the right holder or the infringer's illegal income, if the actual loss of the right holder or the infringer's illegal income is difficult to calculate, the right can be used as a fee reference. In case of intentional infringement of copyright or related rights, if the situation is serious, compensation can be awarded not less than once and not more than five times the amount determined according to the above method.

2) If it is difficult to calculate the true loss of the right holder, the violator's illegal income, and royalties, the court may decide based on the circumstances of the infringement that is, provide compensation of not less than 500 yuan but not more than 5 million yuan.

3) The amount of compensation must also include reasonable fees paid by the rights holder to stop the infringement.

4) To determine the amount of compensation, the court provides the burden of proof to violators. Because the bookkeeping (account book) and material related to the violation most of which are in the hands of violators, so that they can order violators to provide books (account books) and materials related to violations. If the violator does not provide or provides forged books, counterfeit materials, etc., then the Court may determine the amount of compensation by referring to the claim of the right holder and the evidence provided. ${ }^{25}$.

From Copyright Law Settings In the People's Republic of China elements are obtained to calculate compensation on violation copyright are:

1) Compensation is calculated based on losses actually from the right holder.

2) Based on the illegal income of the offender.

3) Compensation for costs incurred by rights holders in an effort to stop violations.

4) In case of violation intentional copyright or related rights, if the situation is serious, compensation can be awarded not less than once and not more than five times the amount determined according to the above indemnity method.

5) Even if the loss the actual rights holder or illegal profits/income

24 Ibid., Article 53.

25 Ibid., Article 54. 
from the violator cannot be determined, the court may decide the compensation value based on the level of the violation, that is, not less than 500 yuan but not more than 5 million yuan.

6) The amount of compensation must also include reasonable fees paid by the rights holder to stop the infringement.

7) To determine the amount of compensation, the court assigns the burden of proof to the violator to provide books (account books) and materials related to violations.

8) If the violator does not provide, or provides forged books, materials, etc., the court may determine the amount of compensation by referring to the rights holder's claim and the evidence provided.

Based on the discussion on the calculation of compensation in the Chinese copyright law above, it is clear that the Copyright Law of the People's Republic of China of 2020 has undergone rapid development to protect the rights of copyright holders or related rights holders in terms of calculating the amount of compensation in case of copyright infringement.

Table 1.

Comparison of Calculation Formulations Amount of Compensation For Copyright Infringement Among Indonesia and the People's Republic of China Law

\begin{tabular}{|c|c|c|}
\hline No. & Indonesia & People's Republic of China \\
\hline 1. & $\begin{array}{l}\text { Constitution Number } \\
20 \text { of } 2014 \text { concerning } \\
\text { Copyright. }\end{array}$ & $\begin{array}{l}\text { Constitution Copyright in } 2010 \text { and } \\
\text { will be amended to the Copyright Law } \\
\text { in } 2021 \text {. }\end{array}$ \\
\hline 2. & $\begin{array}{l}\text { The calculation } \\
\text { formulation has not } \\
\text { been regulated in the } \\
\text { law. The law only } \\
\text { regulates the right to } \\
\text { file a lawsuit on } \\
\text { violation copyright in } \\
\text { Article } 99 \text {. }\end{array}$ & $\begin{array}{l}\text { The calculation formulation is } \\
\text { regulated in Article } 49 \text { of the Law in } \\
2010 \text { and in Article } 54 \text { of the 2021, } \\
\text { namely: } \\
\text { a) Compensation is calculated based } \\
\text { on losses actually from the right } \\
\text { holder. } \\
\text { b) Based on the illegal income of the } \\
\text { offender. } \\
\text { c) Compensation for costs incurred by } \\
\text { rights holders in an effort to stop } \\
\text { violations. } \\
\text { d) In serious/intentional cases, } \\
\text { compensation is given no less than } \\
\text { once and no more than five times } \\
\text { of the compensation formulation. } \\
\text { e) If the actual loss of the rights } \\
\text { holder and the illegal income of the }\end{array}$ \\
\hline
\end{tabular}




\begin{tabular}{|l|l|l|}
\hline & $\begin{array}{l}\text { violator cannot be calculated, the } \\
\text { court may decide the compensation } \\
\text { value is among } 500 \text { yuan to } 5 \\
\text { million yuan depending on the } \\
\text { severity of the violation. }\end{array}$ \\
\hline
\end{tabular}

b. Trademark Compensation Law

China's Trademark Law is regulated in the Act Brand Trade of the People's Republic of China Of 2019 which is the last amendment of the law previously. The purpose of this law is to strengthen the management of brands, protect the exclusive rights of brands, urge manufacturers and owners to ensure the quality of goods and services, and maintain brand credibility, protect the interests of consumers, producers and owners, and to promote economic development. ${ }^{26}$

Mark as a sign in the form of an image, logo, name, word, letter, number, color arrangement in two or three dimensions, sound or a combination of these elements to distinguish goods and/or services produced by individuals or legal entities from goods and/or services. Belonging to another person or other legal entity. The role of the brand as part of intellectual property rights in economic development is very important, because the brand is an identity feature of a product and service that guarantees quality to protect consumers. Therefore, the importance of economic development followed by legal developments in order to be able to protect the rights of every brand owner to consumers to get quality assurance for the goods and services purchased.

Like copyrights, trademarks will become objects of dispute for trademark infringement that occurs, because the higher the economic value of a brand, the higher will be the target object for people who are not responsible for violating the mark. The more famous a brand, of course, the economic value attached to the brand will be higher. The importance of the rule of law in anticipating and overcoming any problems and trademark disputes over trademark infringement is regulated in a concrete manner.

Under the law Brand Commerce of the People's Republic of China 2019 Article $57 .{ }^{27}$ There are actions that constitute a trademark infringement as follows:

1) Using the same trademark as its registered mark on the same commodity without the permission of the trademark registrar;

2) Without the permission of the trademark registrar, use a trademark similar to its registered trademark on the same type of goods, or use a trademark identical or similar to its registered

26 Trademark Law of the People's Republic of China 2019, http://www.maxlaw.cn/n/20200110/967805122132.shtml. 
trademark on similar goods, which is likely to cause confusion;

3) Sell goods that violate the exclusive right to use registered trademarks;

4) Falsify or arbitrarily create registered trademark marks belonging to others or sell false or arbitrary registered trademark marks;

5) Without the consent of the trademark registrar, the registered trademark is modified and goods with the modified trademark are re-marketed;

6) Deliberately providing convenience for violations exclusive rights of trademarks of others, and assisting others to implement infringement of exclusive rights of trademarks;

7) Causing other damage to the exclusive right of others to use registered trademarks.

The actions mentioned above can also be said as a criterion trademark infringement, the above criteria are clearly more detailed than the criteria for infringement in the Act Brand in Indonesia, namely in article 83 paragraph (1) "The owner of a registered mark and/or licensee can file a lawsuit" against other parties who unlawfully use a mark that has similarities in principle or in its entirety for the same type of goods and/or services".

In addition, the China National Intellectual Property Administration ("CNIPA") which is the Department in charge of intellectual property, issuing Assessment criteria for Brand Infringement Trade to better implement the decisions and arrangements of the State Council on strengthening intellectual property protection, strengthening the PRC Trademark Law and the Implementation of Regulations related to the enforcement of Trademark Law through fostering, and unifying law enforcement standards for local authorities and Courts ${ }^{28}$. With Criteria Rating for Brand Infringement Trade will improve the trademark protection system, increase the level of law enforcement protection, solve new problems in law enforcement, provide specific application guidance of trademark law and regulation for law enforcement, and create transparent and predictable intellectual property protection for market participants thereby helping trademark owner to resolve infringement trademarks, especially with the development of internetrelated businesses, brand infringement has become diverse and complex. The Assessment Criteria for Trademark Infringement are as follows ${ }^{29}$ :

1) Trademark use

2) Identical and similar goods and services

3) Brand identical and similar

28 China Trademark Law of 2019 https://www.cms-lawnow.com/ealerts/2020/07/judgingcriteria-for-trademark-infringements?cc lang=en.

29 Ibid. 
4) Misleading action

5) Constitution violation trademark

6) Seller's liability waiver

7) Other important provisions

Constitution Brand Trade of the People's Republic of China regulates against violations that occurs under article 57 that it is obligatory to negotiate the violation that occurred, if the negotiations do not want to be carried out or the negotiations fail, then the interested party can report to the Court or ask the Department of Administration for Industry and Trade to handle it.

If the Department of Administration for Industry and Commerce declares that a violation has occurred, then must immediately stop the infringement, confiscate and destroy the infringing goods and the tools mainly used to manufacture the infringing goods and falsify the registered trademark mark, and the amount of illegal business over 50,000 yuan is punishable by a fine of less than five times the amount of illegal business, if there is no amount of illegal business or the amount of illegal business is less than 50,000 yuan, a fine of less than 250,000 yuan may be imposed. Those who commit trademark infringement more than twice in five years or have other serious circumstances will be severely punished. Meanwhile, for compensation for violations that occur, you can request mediation by the Administrative Department for Industry and Trade, if mediation does not find an agreement, you can file a lawsuit $^{30}$. In Court in accordance with the Civil Procedure Code of the People's Republic of China.

Then for any brand infringement, the calculation compensation on violation trademark in law Brand Trade of the People's Republic of China is regulated in Article 63, namely:

1) Amount of compensation for violations the exclusive right to use the trademark will be determined according to the loss actually suffered by the right holder because of the violation; if the actual loss is difficult to determine, it can be determined in accordance with the gains obtained by the violator due to the violation; loss or violation of rights holders if it is difficult to determine the benefits to which the person derives, it must be reasonably determined by reference to a multiple of the trademark license fee. For malicious infringement of the exclusive use rights of trademarks, if the situation is serious, the amount of compensation can be determined more than once and less than five times the amount determined according to the above method. The amount of compensation must include the reasonable costs paid by the rights holder to stop the infringement. 
2) To determine the amount of compensation, the court may order the violator to provide books (account book) and information related to the violation; if the right holder has tried his best to provide evidence and the books (account books) and information related to the violation are mostly in the hands of the violator; if the violator does not provide or if the books and materials are forged, then the court may refer to the rights holder's claim and the evidence provided to determine the amount of damages.

3) If it is difficult to determine the loss actually suffered by the right holder as a result of the violation, the infringer's profit due to the infringement, and the license fee for the registered trademark, the court will compensate less than 5 million yuan based on the circumstances of the infringement. ${ }^{\prime \prime 11}$

Article 63 above states clearly the calculation compensation value on violation brand. Counting which clearly provides a reference or legal basis for judges in deciding the value of compensation which the plaintiff should have obtained for brand infringement.

Table 2.

Comparison of Calculation Formulations Amount of Compensation For Brand Infringement Among Indonesia and People's Republic of China

\begin{tabular}{|c|c|c|}
\hline No. & Indonesia & People's Republic of China \\
\hline 1. & $\begin{array}{l}\text { Constitution Number } 28 \\
\text { of } 2016 \text { concerning } \\
\text { Brands and Geographical } \\
\text { Indications. }\end{array}$ & Constitution Brand of 2019. \\
\hline 2. & $\begin{array}{l}\text { The calculation } \\
\text { formulation has not been } \\
\text { regulated in the law. The } \\
\text { law only regulates the } \\
\text { right to file a lawsuit on } \\
\text { violation trademark in } \\
\text { Article } 83 \text { paragraph (1). }\end{array}$ & $\begin{array}{l}\text { The calculation formulation is } \\
\text { regulated in Article } 63 \text {, namely: } \\
\text { a) Loss what the right holder actually } \\
\text { suffers because of the violation. } \\
\text { b) If the actual loss of the rights holder } \\
\text { is difficult to quantify, it can be } \\
\text { determined by the illegal profits that } \\
\text { the violator derives from the } \\
\text { infringement the. } \\
\text { c) If the rights holder's losses and the } \\
\text { infringer's income are also difficult } \\
\text { to quantify, it can be determined by } \\
\text { reference to multiples of the brand } \\
\text { license fee. } \\
\text { d) If the rights holder's losses, the } \\
\text { infringer's illegal income, and the }\end{array}$ \\
\hline
\end{tabular}




\begin{tabular}{|l|l|}
\hline \multirow{2}{*}{} & $\begin{array}{l}\text { trademark license fee are difficult to } \\
\text { quantify, the court may decide the } \\
\text { loss is less than } 5 \text { million yuan } \\
\text { based on the severity of the } \\
\text { infringement. }\end{array}$ \\
\hline
\end{tabular}

\section{CONCLUSION}

The law for compensation that arises as a result of copyright and trademark infringement according to positive law in Indonesia still does not regulate in detail the calculation of the value of the loss of both copyrights and trademarks. Copyright Act No.28 of 2014 and Trademark Act No.20 of 2016 only gives rights to the right owner/right holder to file a claim for compensation, but the law does not regulate how to determine the value of the loss for a copyright infringement as well as brands. Unlike the case in the People's Republic of China which regulates the law of compensation for copyright and trademark infringement with more. The Copyright Law of China of 2020 and the Law of Trademarks of China of 2019 have each regulated the calculation of the value of losses for infringement violation. Of course, copyright and trademarks in Indonesia can imitate the copyright laws and trademark laws of the People's Republic of China in regulating more clearly the calculation of the value of losses for copyright and trademark infringement in order to be able to provide legal certainty for rights owners/holders rights that have been violated. It still guided and adhered to by adjusting to Pancasila which is the source of all legal sources in Indonesia.

\section{BIBLIOGRAPHY}

\section{Books:}

Butarbutar, Elisabeth Nurhaini, 2012, Hukum Harta Kekayaan Menurut Sistematika KUHPerdata dan Perkembangannya, Refika Aditama, Medan;

Dewi, Chandra Gita, 2019, Penyelesaian Sengketa Pelanggaran Merek, Deepublish, Jakarta;

Firmansyah, Hery, 2011, Perlindungan Hukum Terhadap Merek, Pustaka Yustisia, Yogyakarta;

Kantaadmadja, Mieke Komar, Ahmad M., and Ramli, 2007, Perlindungan Atas Hak Kekayaan Intelektual Masa Kini Dan Tantangan Menghadapi Era Globalisasi Abad 21, Alumni, Bandung;

Nasution, Rahmi Jened Parinduri, 2013, Interface Hukum Kekayaan Intelektual dan Hukum Persaingan (penyalahgunaan HKI), PT. RajaGrafindo Persada, Jakarta;

Rosidi, Ajib, 2002, Undang-undang Hak Cipta Pandangan Awam, Djambatan, Jakarta; 
Sadino, Oetarid, 1993, Pengantar IImu Hukum (Terjemahan Ineiding tot de Studie van het Nederlandse Recht karangan L.J. van Apeldoorn), Pradnya Paramita, Jakarta;

Saidin, OK, 2002, Aspek Hukum Hak Kekayaan Intelektual, Rajawali Pers, Jakarta;

Sukadana, I Made, 2012, Mediasi Peradilan (Mediasi Dalam Sistem Peradilan Perdata Indonesia Dalam Rangka Mewujudkan Proses Peradilan Yang Sederhana, Cepat dan Biaya Ringan), PT. Prestasi Pustaka Publisher, First Printed, Jakarta;

Ali, Zainuddin, 2012, Metode Penelitian Hukum, Sinar Grafika, Jakarta;

\section{Journals:}

Ahmad M. Ramli, Rika Ratna Permata etc, Pelindungan Kekayaan Intelektual Dalam Pemanfaatan Teknologi Informasi Di Saat Covid-19, Jurnal Penelitian Hukum De Jure Volume 21 Nomor 1, March 2021;

Anis Mashdurohatun, Lily Mariam Nasution, Copyright Transfer of Inheritance Based on Justice Value, International Journal of Innovation, Creativity and Change, Volume 12, Issue 12, 2020;

Chuasanga A., Ong Argo Victoria. (2019). Legal Principles Under Criminal Law in Indonesia and Thailand, Jurnal Daulat Hukum, Vol 2, No 1, 2019;

Fajar, Mukti, Yati Nurhayati, and Ifrani. Itikad Tidak Baik Dalam Pendaftaran Dan Model Penegakkan Hukum Merek di Indonesia. Jurnal Hukum IUS QUIA IUSTUM, No. 2, Volume 25, 2018;

Fathoni. Paradigma Hukum Berkeadilan Dalam Hak Kekayaan Intelektual Komunal, Jurnal Cita Hukum Volume II, No. 2, 2014;

Labetubun, Muchtar Anshary Hamid. Aspek Hukum Hak Cipta Terhadap Buku Elektronik (E-Book) Sebagai Karya Kekayaan Intelektual, Jurnal SASI, Volume 24, No. 2, 2018;

Mamahit, Jisia. Perlindungan Hukum Atas Merek Dalam Perdagangan Barang Dan Jasa, Jurnal Lex Privatum, Volume 1, No. 3, 2013;

Maria Alfons, Implementasi Hak Kekayaan Intelektual Dalam Perspektif Negara Hukum, Jurnal Legislasi Indonesia, Vol. 14 No. 03 September 2017;

Oksidelfa Yanto, Konsep Perlindungan Hak Cipta Dalam Ranah Hukum Hak Kekayaan Intelektual (Studi Kritis Pembajakan Karya Cipta Musik dalam Bentuk VCD dan DVD), Yustisia, Vol. 4 No. 3 September-December 2015;

\section{Internet:}

cms-lawnow.com, Judging Criteria for Trademark infringements, https://www.cms-lawnow.com/ealerts/2020/07/judging-criteriafor-trademark-infringements?cc lang=en. 
Maxlaw.cn., Undang-Undang Merek Republik Rakyat China (Tiongkok) tahun 2019, http://www.maxlaw.cn/n/20200110/967805122132.shtml.

Sohu.com., Amandemen Ketiga Undang-Undang Hak Cipta Republik Rakyat China (Tiongkok) 2020, https://m.sohu.com/a/431202010718349 